\title{
TRDMT1 Gene
}

National Cancer Institute

\section{Source}

National Cancer Institute. TRDMT1 Gene. NCI Thesaurus. Code C105560.

This gene is involved in methylation of aspartic acid transfer RNA. 